\title{
Strengthening Success Factors and Overcoming Profitability Barriers towards Sustainable Project Management Consultant Companies
}

\author{
Edgar B. Bernardino (Corresponding author) \\ Graduate School, Philippine Christian University, Middle East Campus, Qatar \\ Tel: 974-5576-1872_E-mail: edgar_bernardino@yahoo.com
}

Kryslen M. Serona

Graduate School, Philippine Christian University, Middle East Campus, Qatar

Tel: 974-7098-1751Ｅ-mail: kryserona@gmail.com

Jowell C. Cando

Graduate School, Philippine Christian University, Middle East Campus, Qatar

Tel: 974-7098-1751Ｅ-mail: engr_jowell28@yahoo.com

\author{
Imee C. Acosta \\ FDES \& GDES Department, Virginia Commonwealth University Qatar \\ P.O. Box 8095, Al Luqta Street, Education City, Doha, Qatar \\ Tel: 974-5515-3642_Email: imeecacosta@yahoo.com
}

Eduardo P. Malagapo

Administration Department, Al Andalus International School

Ar Rakah Al Janubiyah, Al Khobar 34226, Saudi Arabia

Tel: 966-506-802-972Ｅmail: drepmalagapo@gmail.com

Received: April 14, 2018 Accepted: April 29, 2018 Published: May 29, 2018

doi:10.5296/ber.v8i2.13003 URL: https://doi.org/10.5296/ber.v8i2.13003 


\section{Abstract}

Project success can be assured by identifying, reducing, and eliminating the impact of profitability barriers; and by understanding and exploring the success factors in order to achieve sustainable profitability of Project Management Consultant (PMC) companies. Currently, practices of project management consultants in the construction industry sector do not always ensure project success. Thus, this paper aims to assess and strengthen the success factors; and overcome profitability barriers to improve effectiveness of project delivery. Using Porter's five forces model as profitability barriers, areas with the highest impact to sustainable profitability were investigated. Data were gathered through a survey questionnaire and purposive sampling technique was used to select 140 respondents who are working in a project management and consulting company in Doha, Qatar for the year 2016-2017. The findings revealed that profitability barriers such as: power of suppliers, industry competition, and impact of new entrants are correlated to some of the areas of success factors, such as: effective project management, efficient cost leadership, competitive differentiation, and strategic alliances and networking. Sustainable profitability is significantly affected by the power of suppliers, and strategic networking and alliance. Whereas, competitive differentiation significantly affects profitability barriers. Based on the findings of this study, recommendations were given on how to strengthen project success factors and reduce the impact of profitability barriers.

Keywords: Profitability Barriers, Success Factors, Sustainability, Project Management, Porter's Five Forces, Competitive Advantage, Business

\section{Introduction}

Managing projects effectively and achieving sustainable profitability are the life blood of project management consultants (PMCs) (Gilmore 2017; Cullen, n.d.). Leaders in PMCs are striving to run their companies successfully to attain sustainable profitability and capability of growing and attracting the very best clients (Brueggen, 2015). A PMC team needs to be guided towards performing sustainable work practices and by developing sustainable products and services for effective delivery of projects (Silvius, et al., 2017). According to Gilmore (2017), successful projects rely on every stage of their lifecycle, from securing the initial win, to managing scope and delivering on time and at a profit. Many PMCs already believe that they have good project control in place and that they are able to deliver all of their projects successfully and profitably (Brueggen, 2015). But it is still common for PMCs to suffer the shock realization that the projects they have been delivering are turning out to be unsuccessful and unprofitable (Green, 2015). Many previous studies have been devoted to define, clarify and analyze the factors that caused the failures and successes of projects (Söderlund, 2004; Elkadi, 2013; Belassi \& Tukel, 1996; Hyvari, 2006) in order to minimize failure factors and strengthen success factors. Additionally, project success can also be assured by identifying and eliminating the profitability barriers that cause poor project outcomes (Taherdoost \& Keshavarzsaleh, 2016). In Qatar, some PMCs failed to achieve sustainable profitability despite of the abundance of projects required for Qatar's preparation for the FIFA World Cup 2022 and implementation of Qatar National Vision 2030 (Dávalos, 
2017). The country is investing heavily in developing infrastructure and construction projects, with USD 220+ billion to be invested in new roads, stadiums, facilities, and numerous major projects including hotels, leisure, and recreation in the planning or construction phase (Project Qatar, 2017; The Guardian, 2017; ME Steel, 2017). However, in some cases, some projects in Qatar have stopped or have been delayed due to a number of factors such as escalating cost of building materials, changes to project designs, massive cost overruns, among others (Withers, 2017; Atkinson, 2017; Kerr, 2017; Walker, 2016). A very concrete example is the Sidra Hospital project which was originally set to open in 2011 but has faced repeated delays in recent years (Attwood, 2016; Kovessy, 2015; Scott, 2014; Onsite Ventures, 2014). The case of Sidra Hospital is an exemplar of project failure that affects the sustainable profitability of a project consultant company.

With the growing concern of project delay and failure, this paper contends that assessing the success factors and profitability barriers can have a positive outcome on project success. Apparently, there are many factors outside the control of management which could determine the success or failure of a project (Belassi \& Tukel, 1996). In this study, these factors are referred to as success factors and profitability barriers. Although, several studies have been done on the reasons for project failure, but the area on assessing the success factors and profitability barriers for sustainable profitability of project management consultant companies in Qatar is underexplored. Hence, this paper attempts to discuss how to strengthen the success factors and reduced the impact of profitability barriers for sustained profitability of PMC companies. The findings reported in this study provided the empirical bases for the relationship between and among profitability barriers, success factors, and sustainable profitability strategies of PMC companies. Using Porter's five forces model as profitability barriers, areas with the highest impact to sustainable profitability were investigated. It is hoped that the result of the study would help sustain and optimize profitability of PMC companies in Qatar and the rest of the world. Furthermore, the results can be used as a guiding principle for the existing PMCs to restructure and innovate their strategies for overcoming profitability barriers, thus, achieving sustainable profitability.

\section{Literature Review}

\subsection{Success Factors}

Success factors are indicators that constitute a model of the system of interest, in order to guide strategy selection, implementation and monitoring (Moldan and Billharz, 1997 cited in Taherdoost \& Keshavarzsaleh, 2016). It is a measure of efficiency that provides a good indicator for the success of any project (Nenni, Giustiniano, \& Pirolo, 2013). These are known as tools for measuring performance in an organization to achieve company profitability (Business Victoria, n.d.). Pinto and Slevin (1988) identified that project success is measured based on these characteristics: adherence to budget, adherence to schedule, level of performance achieved, technical validity, organizational validity, and organizational effectiveness. However, Taherdoost \& Keshavarzsaleh, (2016) stressed on the importance of comprehending the success factors and mutual interactions between them. All projects should be supportive of the organizations strategic goals to have a successful project. As suggested 
by Tsiga, et. al. (2016), new entrants and established companies in the construction industry, such as project management consultant, can use these factors to help themselves in successful project delivery for future projects such as desirable organizational practices, effective project management, efficient cost leadership, competitive differentiation, and strategic alliances or networking (Bakar et. al., 2011; Mohamad et. al., 2013; Martin, 2017; Porter, 2004).

\subsection{Profitability Barriers}

Porter's five forces model was used to determine the profitability barriers that affect sustained profitability of project management consultant companies.

Industry Competition. The prevailing competition and rivalry of the existing firms in the construction market that offer similar products or services is referred to as industry competition that affects a company's profitability, costs, and products (Pamulu, 2010). Many project management and construction companies are involved in submitting competitive tenders to win contracts that denotes a strong competition, hence, considered a profitability barrier for most PMC companies (Finch, 2011). In the overcrowded market of the construction industry, big PMCs and construction companies usually dominate the market since they own a big share, predominantly on the large-scale projects (Levinson, 2007). This factor can be seen as a profitability barrier for small and medium companies that usually land in small scale projects. But could also be a profitability barrier for large PMCs that do not diversify their clients and services.

Power of Suppliers. The supplier mainly affects the profitability and product competitiveness of the existing enterprises in the industry through its ability to improve the input factor price and reduce the unit value quality (Kanakulya \& Jinzhao, 2017). The supplier's strength depends primarily on its ability to control the firm's quality products and has the power to increase or decrease its prices to recover some losses or to gain its profits (Pamulu, 2010). When the value of the inputs provided by the supplier constitutes a large proportion of the total cost of the buyer's product, and it is important for the production process of the buyer, or seriously affects the quality of the buyer's products, the supplier's potential bargaining power is greatly enhanced relative to buyers (Kanakulya \& Jinzhao, 2017). In this scenario, Porter's model is based on the assumption that when suppliers are powerful, they can exert pressure on the producers to capture some of the project management and construction industries' profits. The fewer there are, the more power they have (Öney-Yazýcý \& Acar, 2006; Martin, 2017).

Power of Customers. Customer power refers to the impact of clients on an industry (Öney-Yazýcý \& Acar, 2006; Wilkinson, 2013). Customers are not very loyal. They can easily switch to a competitor's offering for little cost (Finch, 2011) which would likely cause a profitability barrier for the PMC company or client when the contractor selected based on lowest cost fails to deliver and the quality is not as per the client expectation and requirement (Hafez \& Aziz, 2013). This scenario is a fact in the construction industry where project management and construction clients are usually fewer than the contractors available to deliver the project. The fewer the client, the stiffer the competition among the contractors that cause a profitability barrier for them (WBDG Project Management, 2017). Thus, customer 
power also affects pricing and quality. Their bargaining power can pressure the contractors to get them to provide higher quality products, better customer service, and lower prices. Buyer power is one of the forces that shape the competitive structure of an industry (Martin, 2014).

Impact of New Entrants. The threat of new entry will depend on the existence of barriers to entry and the reaction that entrants can expect from existing competitors (Pamulu, 2010). Its impact in the market can weaken the company's market position (Taherdoost \& Keshavarzsaleh, 2016). Porter believed that the possibility of new entrants has a significant part to play in developing and changing the competitive dynamics of any industry. If there is a higher threat of new entrants, this means that there are low barriers to entry and there is high possibility that the company profitability will decrease (Martin, 2014). Hence, it is important for a firm to achieve the project objectives in terms of proper planning and controlling of the pre-defined activities with the efficiency of the time and costs and by applying a collection of tools and techniques (Taherdoost \& Keshavarzsaleh, 2016). Maintaining the company's image and producing high quality services can help the company's stability amidst the impact or threats of the new competitors in the market.

Impact of Substitutes. A company is threatened if another company produces a similar product or service or if consumers of that product or service can decrease the ratio of their use of that product or service and use another product or service provider (Selim and Salem, 2014). Both of these choices are existent to project management consultant clients or consumers, hence the threat of substitutes is high and becomes a profitability barrier. This signifies how easy it is for consumers to switch from one service provider or product to that of a competitor. Martin (2017) asserted that the threat of substitutes is informed by switching costs, both immediate and long-term, as well as a buyer's inclination to change. The threat of substitution in the construction industry affects the competitive environment for PMCs and influences their ability to achieve profitability as clients can choose to procure the substitute with cheaper cost (Wilkinson, 2013). PMCs inability to cope with new and emerging innovative methods and processes within project management \& construction industry increases the threat of substitutes. Therefore, PMCs should assess the opportunities inherent in the new technologies and materials, and then adjust their processes, operations and even business models accordingly (de Almeida, et al., 2016).

\subsection{Strategies for Sustainable Company Profitability}

There are 10 strategies considered for sustainable profitability in this is study, adapted from Mochal (2016). (1.) Plan the work by utilizing a project definition document. A detailed and clear project definition document shall be established from the planning stage up to completion; and planning the work based on the established project document as a basis in executing the project are critical. (2.) Create a planning horizon. This suggests that in big projects, it is not feasible to plan out the whole project in detail as this will increase the level of uncertainty for a project. It is therefore recommended to plan only the detail that is comfortable for the team and in the current phase of the project that the team is involved (Aston, 2013). (3.) Define project management procedures up front to ensure that the project team and all stakeholders have a common understanding of how the project will be managed. 
(4.) Manage the work plan and monitor the schedule and budget. A work plan is a vital tool for ensuring that the project manager and project team know what they need to do to complete the project as per agreed schedule (Serrador, 2013). Harned (2015) recommended that once the work plan is established, the Project Manager must effectively manage the work plan and give considerable attention to monitoring schedules and budget. (5.) Look for warning signs. These are any indication, proof, or sign of the existence of some future negative issues that shall be observed all the time and PMC team should raise visibility through risk management, and put together a plan to proactively ensure that the project stays on track (Mochal, 2016). (6.) Ensure that the client approves scope-change requests. Any change in the project has the potential cost and time impact for the client. Hence, PMCs must ensure that all scope change request are duly approved by the client before instructing the contractor to execute the said work (Millhollan, 2008). (7.) Guard against scope creep. Based on the agreed scope, a procedure for dealing with additions and improvements must be established and any change in scope must be raised and approved (as a variation) by the client (Muhammed, 2016). (8.) Identify risks up front. Risks must be identified up front and the necessary measures must be established to minimize if not eliminate negative impact on cost, time and quality of the project (Kwon and Kim, 2004). (9.) Continue to assess potential risks throughout the project. Risks shall be managed systematically, and risk management should be done continuously throughout the life of a project for PMC Company to achieve significant cost savings for a project (Antón, Rodríguez, López, 2011). (10.) Resolve issues as quickly as possible. Mochal (2005) recommended that any issues that arise must be quickly resolved through a systematic approach by means of identifying the problem, determining the causes, selecting the best solution, and taking necessary action.

\section{Objectives of the Study}

This paper aims to determine the perceived success factors and profitability barriers to sustainable profitability of PMCs; probe the relation between success factors and profitability barriers; and identify the success factors and profitability barriers with the highest impact to sustainable profitability of PMCs.

\section{Method}

\subsection{Study Design}

The study used quantitative descriptive method (Labaree, 2009; Sousa, Driessnack, \& Mendes, 2007). This research approach is a basic research method that examines the situation, as it exists in its current state. It involves identification of attributes of a particular phenomenon based on an observational basis, or the exploration of correlation between two or more phenomena (Williams, 2011; Patel, 2009).

\subsection{Research Participants}

The participants of the study were the 180 employees working in a project management and consulting company in Doha, Qatar for the year 2016-2017. The target response was at least $70 \%-80 \%$ of the 180 distributed questionnaires. Therefore, for this study, a minimum of 126 and a maximum of 140 response rate was deemed appropriate, having a $95 \%$ confidence level 
at an interval of $+/-5 \%$. A return rate of $78 \%$ was obtained and the usable response percentage was $99 \%$.

\subsection{Research Instrument}

This study utilized a survey questionnaire adapted from Bakar, et. al. (2011); Mohamad, et. al. (2013); Martin (2017); and Porter (2004). The questionnaire was composed of four parts, part 1 sought the respondents' profile, part 2 determined the success factors, part 3 determined the profitability barriers, and part 4 strategies for sustainable company profitability. The questionnaire has a total of 60 -item statements followed by a 5-point scale asking the respondents how much the statement is observed or not observed based on the following scales: 1 -Not Observed (NO), 2 -Very Rarely Observed (VRO), 3 -Sometimes Observed (SO), 4 -Observed most of the time (OMTT), 5 -Observed all the time (OATT).

\subsection{Data Collection}

The procedure in gathering the data consists of the following steps: step 1: employees in project management and consultancy company were identified; step 2: seeking of permission from the target respondents to conduct the research; step 3: actual administration of the survey questionnaires to be filled-up by the respective employee; step 4: retrieval of completed questionnaires.

\subsection{Cronbach Alpha Reliability Test}

Content validity was determined using the Cronbach's Alpha coefficients (Trizano-Hermosilla \& Alvarado, 2016). The calculated Cronbach Alpha coefficients of the survey questionnaire are as follows: success factors $(\alpha=.839)$, profitability barriers $(\alpha=.771)$, and strategies for sustainable profitability $(\alpha=.887)$. Therefore, the survey instrument used in this study has a relatively excellent internal consistency (George \& Mallery, 2003 cited in Gliem \& Gliem, 2003).

\subsection{Data Analysis}

Collected data were tallied and analyzed with descriptive, correlation, and multiple regression statistical techniques using the Statistical Package for the Social Sciences (SPSS) Software V21 x64.

\section{Findings}

\subsection{Perceived Success Factors and Profitability Barriers}

Table 1. Perceived Success Factors

\begin{tabular}{|l|c|c|l|}
\hline \multicolumn{1}{|c|}{ Success factors } & Mean & Rank & \multicolumn{1}{c|}{ Description } \\
\hline Desirable organizational practices & 4.46 & 1 & Observed all of the time \\
\hline Effective project management & 4.44 & 2 & Observed all of the time \\
\hline Strategic Alliance/Networking & 4.36 & 3 & Observed all of the time \\
\hline Efficient cost leadership & 4.30 & 4 & Observed all of the time \\
\hline Competitive differentiation & 4.14 & 5 & Observed most of the time \\
\hline
\end{tabular}




\begin{tabular}{|r|l|l|l|}
\hline Grand Mean & 4.34 & & Observed all the time \\
\hline
\end{tabular}

One of the aims of this paper was to determine the perceptions of respondents on success factors on the areas of desirable organizational practices, effective project management, efficient cost leadership, competitive differentiation, and strategic alliance/networking. The collective result implied that the respondents evaluated success factors as "observed all the time" supported by the grand mean of 4.34. This suggests that the four indicators of success factors should be strengthened especially in the area of desirable organizational practices, effective project management, strategic alliance/networking, and efficient cost leadership; while competitive differentiation needs some initiative by the company to improve.

Table 2. Perceived Profitability Barriers

\begin{tabular}{|l|l|l|l|}
\hline $\begin{array}{l}\text { Profitability Barriers } \\
\text { using Porter's 5 Forces Model }\end{array}$ & Mean & Rank & Description \\
\hline Industry competition & 3.82 & 1 & Observed most of the time \\
\hline Impact of new entrants & 3.69 & 2 & Observed most of the time \\
\hline Power of customers & 3.68 & 3 & Observed most of the time \\
\hline Power of suppliers & 3.57 & 4 & Observed most of the time \\
\hline Impact of substitutes & 3.51 & 5 & Observed most of the time \\
\hline Grand Mean & 3.65 & & Observed most of the time \\
\hline
\end{tabular}

The report on table 2 shows the summary perception of the respondents to profitability barriers. It appears that their perception yielded a grand mean of 3.65 described as "observed most of the time". A potential approach to address the profitability barriers is for PMCs' to continuously revisit and innovate their strategies to remain at a competitive advantage and sustain profitability.

\subsection{Correlation Analysis}

Table 3. Correlation Matrix between Success Factors and Profitability Barriers

\begin{tabular}{|l|l|l|l|l|l|l|l|l|l|l|}
\hline & \multicolumn{7}{|l|}{ Success Factors } \\
\hline \multirow{2}{*}{$\begin{array}{l}\text { Profitability } \\
\text { Barriers }\end{array}$} & \multicolumn{2}{|l|}{$\begin{array}{l}\text { Desirable } \\
\text { organizational } \\
\text { practices }\end{array}$} & $\begin{array}{l}\text { Effective } \\
\text { project } \\
\text { management }\end{array}$ & \multicolumn{2}{l}{$\begin{array}{l}\text { Efficient cost } \\
\text { leadership }\end{array}$} & $\begin{array}{l}\text { Competitive } \\
\text { differentiation }\end{array}$ & \multicolumn{2}{l|}{$\begin{array}{l}\text { Strategic } \\
\text { alliances }\end{array}$} \\
\cline { 2 - 13 } & $(\mathrm{r})$ & $(\mathrm{p})$ & $(\mathrm{r})$ & $(\mathrm{p})$ & $(\mathrm{r})$ & $(\mathrm{p})$ & $(\mathrm{r})$ & $(\mathrm{p})$ & $(\mathrm{r})$ & $(\mathrm{p})$ \\
\hline $\begin{array}{l}\text { Industry } \\
\text { competition }\end{array}$ & .000 & .999 & .073 & .394 & $.201^{*}$ & .017 & $.220^{* *}$ & .009 & $.279^{* *}$ & .001 \\
\hline $\begin{array}{l}\text { Power of } \\
\text { suppliers }\end{array}$ & .068 & .425 & $.180^{*}$ & .033 & $.177^{*}$ & .036 & $.303^{* *}$ & .000 & $.211^{*}$ & .013 \\
\hline $\begin{array}{l}\text { Power of } \\
\text { customer }\end{array}$ & .034 & .694 & .120 & .156 & .093 & .277 & .097 & .254 & .026 & .761 \\
\hline $\begin{array}{l}\text { Impact of } \\
\text { new entrants }\end{array}$ & .074 & .383 & .154 & .069 & $.217^{* *}$ & .010 & .122 & .149 & .137 & .106 \\
\hline Impact of & -.017 & .838 & .015 & .860 & .025 & .766 & .018 & .037 & -.105 & .216 \\
\hline
\end{tabular}


substitutes

$* * \mathrm{p}=.01$ level (2-tailed) $\quad * \mathrm{p}=.05$ level (2-tailed)

Correlation is interpreted as follows (Calmorin, 1984): 0.00-0.20 (Low); 0.21-.40 (Slight); 0.41-0.70 (Substantial); 0.71-1.00 (High)

To probe the relation between success factors and profitability barriers, correlation analysis was carried out. As indicated, industry competition, is correlated to three areas of success factors such as: efficient cost leadership $(\mathrm{r}=.201, \mathrm{p}=.017$, low), competitive differentiation $(\mathrm{r}-.220, \mathrm{p}=.009$, slight), and strategic alliance $(\mathrm{r}=.279, \mathrm{p}=.001$, slight $)$. Power of suppliers is correlated to the four areas of success factors, namely: effective project management $(\mathrm{r}=.180$, $\mathrm{p}=.033$, low), efficient cost leadership ( $\mathrm{r}=.177, \mathrm{p}=.036$, low), competitive differentiation $(\mathrm{r}=.303, \mathrm{p}=.000$, slight $)$, and strategic alliance .211, $\mathrm{p}=.013$, slight $)$. And the degree of correlation between impact of new entrants and efficient cost leadership $(r=.217, p=.010)$ is low. The results implied that effective project management, efficient cost leadership, competitive differentiation, and strategic alliance have something to do with how the company remains competitive and profitable in managing industry competition, power of suppliers, and impact of new entrants.

\subsection{Regression Analyses}

Table 4. Regression Analysis of Success Factors \& Sustainable Profitability

\begin{tabular}{|l|l|l|l|l|}
\hline \multirow{2}{*}{ IV } & \multicolumn{2}{|l|}{ Regression Coefficient } & \multirow{2}{*}{ t value } & \\
\cline { 2 - 3 } & $\mathrm{B}$ & Beta & & Sig. \\
\hline Constant & 23.138 & & & \\
\hline Strategic Alliance & .583 & .308 & 3.545 & .001 \\
\hline Effective project management & .335 & .188 & 2.159 & .033 \\
\hline $\mathrm{R}=.429, \mathrm{R} 2=.184$, Adjusted R2 $=.172$ \\
\hline F statistics $=15.408$, Significance $=.000$
\end{tabular}

The regression of success factors and sustainable profitability is shown on table 4. As reported, two components of success factors are significant, they are: strategic alliance and networking $(\mathrm{B}=.583, \mathrm{t}=3.545$, sig. $=.001)$ and effective project management $(\mathrm{B}=.335, \mathrm{t}$ $=.159$, sig. $=.033)$. The beta regression coefficients are positive. However, among the two significant variables, strategic alliance has a stronger coefficient with a Beta weight of .308 than effective project management with a Beta weight of .188. The $\mathrm{R}$ is .429 with an adjusted R-square of .172 , this indicates that $17.2 \%$ sustainable profitability can be attributed to strategic alliance and effective project management, while $82.2 \%$ could be explained by other factors not mentioned in the study. The F statistics is 15.408 and is significant at .000 . Hence, among the success factors, strategic alliance and effective project management significantly determine sustainable profitability.

Table 5. Regression Analysis of Profitability Barriers \& Sustainable Profitability

\begin{tabular}{|l|l|l|l|}
\hline IV & Regression Coefficient & & \\
\hline
\end{tabular}




\begin{tabular}{|l|l|l|l|l|}
\hline & $\mathrm{B}$ & Beta & $\mathrm{t}$ value & Sig. \\
\hline Constant & 33.422 & & & \\
\hline Power of suppliers & .436 & .258 & 3.132 & .002 \\
\hline $\mathrm{R}=.258, \mathrm{R} 2=.066$, Adjusted $\mathrm{R} 2=.060$ \\
\hline \multicolumn{4}{|l}{ F statistics $=9.808$, Significance $=.002$} \\
\hline
\end{tabular}

The report on table 5, indicated that among the 5 profitability barriers, power of suppliers has the highest impact to sustainable profitability. The regression coefficients are positive $(\mathrm{B}=$ 436 , beta $=.258, \mathrm{t}=3.132$, sig. $=.002)$. The $\mathrm{R}$ is .258 with an adjusted R-square of .060 suggesting that $6 \%$ of the factors that affect sustainable profitability can be attributed to the power of suppliers. While $94 \%$ could be explained by other variables not mentioned in the study. The F statistics is 9.808 and is significant at .002 .

\section{Discussion}

Determining success factors and limiting profitability barriers will give the company a competitive edge and will make the project management company profitable and sustainable.

\subsection{Success Factors}

Currently there are at least 105 companies providing project design \& management services in Doha, Qatar (Qatar Online Directory, 2017). These companies are involved in submitting competitive tenders to win contracts which indicates a strong competition among project management consultant companies (Finch, 2011). The perception that strategic alliance/networking and effective project management significantly determine sustainable profitability, it is apparent that effective project management need to be strengthened through planning, monitoring, and controlling; and by creating strategic alliances for diversification of market sector and services offered to maintain a measure of stability and profitability.

\subsection{Profitability Barriers}

Of the five components of profitability barriers, it was perceived that power of suppliers has the highest impact to sustainable profitability, which could be attributed to the current Qatar embargo that impacts the country's construction and project management sectors. Qatar's construction industry relies partly on the import of construction materials by land and sea from Saudi Arabia and the UAE; the closure of the land border and the shipping ban will force Qatar to find new suppliers of construction materials quickly to avoid a shortage of materials which would cause a disruption to ongoing construction projects and an increase in construction materials' prices (World Construction Network, 2017; Withers, 2017; Atkinson, 2017). In this scenario, the power of suppliers can affect company profitability as suppliers have the ability to raise input prices. However, Qatar has already tackled the challenge of construction suppliers by holding several agreements to open new freighter routes to Hamad International Sea Port, in addition to all other import facilities. The efforts undertaken were to ensure that local demands are met and project schedules are uninterrupted in major construction and development and infrastructure projects, especially projects for FIFA World Cup 2022 and Qatar National Development Vision 2030 (The Peninsula, 2017). 


\section{Macrothink}

Business and Economic Research

ISSN 2162-4860

2018, Vol. 8, No. 2

Drawing on the findings of this paper, parameters that determine the perspectives of the surveyed sector of project management consultant companies in Qatar are outlined in table 6 below.

Table 6. Perceived Parameters of PMCs

\begin{tabular}{|c|c|c|c|c|c|}
\hline Success Factors & & $\begin{array}{l}\text { Profitability } \\
\text { Barriers }\end{array}$ & & $\begin{array}{l}\text { Sustainable Profitability Practices } \\
\text { (Adapted from Mochal, 2016) }\end{array}$ & \\
\hline \multirow{2}{*}{$\begin{array}{l}\text { Desirable } \\
\text { organizational } \\
\text { practices }\end{array}$} & \multirow[t]{2}{*}{+} & \multirow[t]{2}{*}{$\begin{array}{l}\text { Industry } \\
\text { competition }\end{array}$} & \multirow[t]{2}{*}{---} & $\begin{array}{l}\text { Plan the work by utilizing a project } \\
\text { definition document. }\end{array}$ & ++ \\
\hline & & & & Create a planning horizon. & ++ \\
\hline \multirow[t]{2}{*}{$\begin{array}{l}\text { Effective project } \\
\text { management }\end{array}$} & \multirow[t]{2}{*}{+++} & \multirow[t]{2}{*}{$\begin{array}{l}\text { Power of } \\
\text { suppliers }\end{array}$} & \multirow[t]{2}{*}{---} & $\begin{array}{l}\text { Define project management procedures up } \\
\text { front. }\end{array}$ & \\
\hline & & & & $\begin{array}{l}\text { Manage the work plan and monitor the } \\
\text { schedule and budget. }\end{array}$ & +++ \\
\hline \multirow{2}{*}{$\begin{array}{l}\text { Strategic } \\
\text { Alliance/Networking }\end{array}$} & \multirow[t]{2}{*}{+++} & \multirow{2}{*}{$\begin{array}{l}\text { Power of } \\
\text { customer }\end{array}$} & \multirow[t]{2}{*}{--} & Look for warning signs. & + \\
\hline & & & & $\begin{array}{l}\text { Ensure that the client approves } \\
\text { scope-change requests. }\end{array}$ & ++ \\
\hline \multirow{2}{*}{$\begin{array}{l}\text { Efficient cost } \\
\text { leadership }\end{array}$} & \multirow[t]{2}{*}{+} & \multirow{2}{*}{$\begin{array}{l}\text { Impact of } \\
\text { new entrants }\end{array}$} & \multirow[t]{2}{*}{--} & Guard against scope creep. & + \\
\hline & & & & Identify risks up front. & +++ \\
\hline \multirow[t]{2}{*}{$\begin{array}{l}\text { Competitive } \\
\text { differentiation }\end{array}$} & \multirow[t]{2}{*}{++} & \multirow[t]{2}{*}{$\begin{array}{l}\text { Impact of } \\
\text { substitutes }\end{array}$} & \multirow[t]{2}{*}{-} & $\begin{array}{l}\text { Continue to assess potential risks } \\
\text { throughout the project. }\end{array}$ & +++ \\
\hline & & & & Resolve issues as quickly as possible. & +++ \\
\hline
\end{tabular}

Parameters: + Advantageous, ++ Moderately advantageous, +++ Most advantageous

- Disadvantageous, -- Moderately disadvantageous, --- Most disadvantageous

On another note, the findings that have been found through this study could also be applicable to the Contractors of construction projects since they are also directly affected by these factors. For the sake of comparison, the parameters are outlined below.

Table 7. Perceived Parameters as Applied to Contractors

\begin{tabular}{|c|c|c|c|c|c|}
\hline Success Factors & & $\begin{array}{l}\text { Profitability } \\
\text { Barriers }\end{array}$ & & $\begin{array}{l}\text { Sustainable Profitability Practices } \\
\text { (Adapted from Mochal, 2016) }\end{array}$ & \\
\hline \multirow[t]{2}{*}{$\begin{array}{l}\text { Desirable organizational } \\
\text { practices }\end{array}$} & \multirow[t]{2}{*}{++} & \multirow[t]{2}{*}{$\begin{array}{l}\text { Industry } \\
\text { competition }\end{array}$} & \multirow[t]{2}{*}{---} & $\begin{array}{l}\text { Plan the work by utilizing a project } \\
\text { definition document. }\end{array}$ & +++ \\
\hline & & & & Create a planning horizon. & ++ \\
\hline \multirow[t]{2}{*}{$\begin{array}{l}\text { Effective project } \\
\text { management }\end{array}$} & \multirow[t]{2}{*}{+++} & \multirow[t]{2}{*}{$\begin{array}{l}\text { Power of } \\
\text { suppliers }\end{array}$} & \multirow[t]{2}{*}{---} & $\begin{array}{l}\text { Define project management } \\
\text { procedures up front. }\end{array}$ & \\
\hline & & & & $\begin{array}{l}\text { Manage the work plan and monitor } \\
\text { the schedule and budget. }\end{array}$ & +++ \\
\hline \multirow{2}{*}{$\begin{array}{l}\text { Strategic } \\
\text { Alliance/Networking }\end{array}$} & \multirow[t]{2}{*}{+} & \multirow{2}{*}{$\begin{array}{l}\text { Power of } \\
\text { customer }\end{array}$} & \multirow{2}{*}{---} & Look for warning signs. & + \\
\hline & & & & $\begin{array}{l}\text { Ensure that the client approves } \\
\text { scope-change requests. }\end{array}$ & ++ \\
\hline
\end{tabular}




\begin{tabular}{|c|c|c|c|c|c|}
\hline \multirow[t]{2}{*}{ Efficient cost leadership } & \multirow[t]{2}{*}{+++} & \multirow{2}{*}{$\begin{array}{l}\text { Impact of new } \\
\text { entrants }\end{array}$} & \multirow[t]{2}{*}{--} & Guard against scope creep. & + \\
\hline & & & & Identify risks up front. & +++ \\
\hline \multirow[t]{2}{*}{ Competitive differentiation } & \multirow[t]{2}{*}{+} & \multirow[t]{2}{*}{$\begin{array}{l}\text { Impact of } \\
\text { substitutes }\end{array}$} & \multirow[t]{2}{*}{-} & $\begin{array}{l}\text { Continue to assess potential risks } \\
\text { throughout the project. }\end{array}$ & ++ \\
\hline & & & & $\begin{array}{l}\text { Resolve issues as quickly as } \\
\text { possible. }\end{array}$ & +++ \\
\hline
\end{tabular}

Parameters: + Advantageous, ++ Moderately advantageous, +++ Most advantageous

- Disadvantageous, -- Moderately disadvantageous, --- Most disadvantageous

As mentioned earlier, sustainable profitability of project management consultant companies can be attained through strengthened effective project management practices, strategic alliance/networking, and mitigating the power of suppliers. Figure 1 depicted an overview of the implementation of the indicators of sustainability and profitability in the perspective of PMCs.

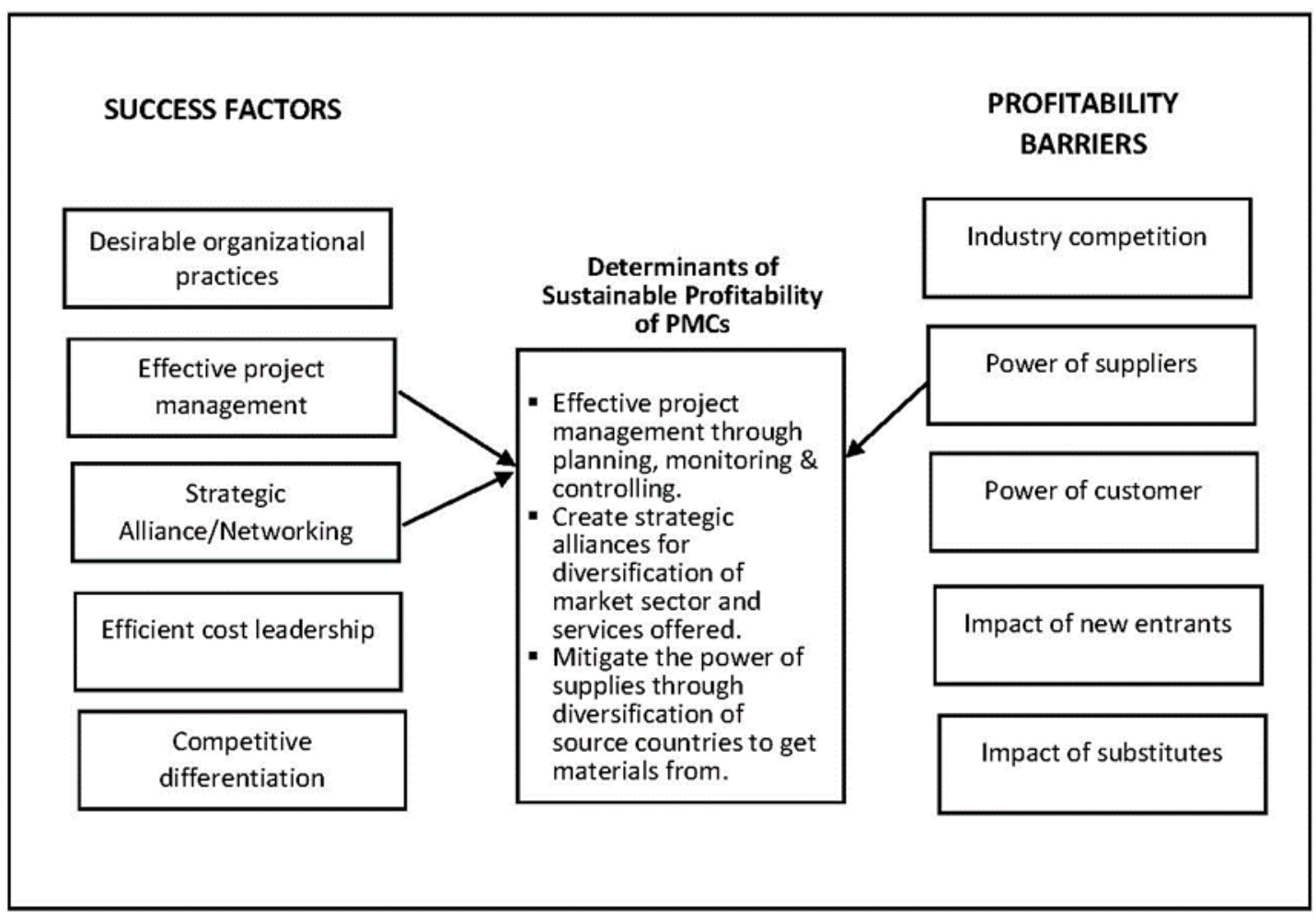

Figure 1. An Overview of implementation of the indicators of sustainability and profitability in the perspective of PMCs

\section{Conclusion \& Recommendations}

The success factors and profitability barriers were evaluated based on the participants' perceptions. The results show that among the success factors, strategic alliance and effective project management significantly determine sustainable profitability. While power of suppliers has the highest impact to sustainable profitability among the profitability barriers. In order to sustain profitability for PMCs, the researcher highly recommends to improve the 
success factors through enhancing techniques and methods associated with skills that include effective management of time, cost and scope; and improve the effectiveness of project delivery. Effective project management can be strengthened through planning, monitoring \& controlling. Whilst strategic alliance/networking can be done through the creation of strategic alliances for diversification of market sector and services offered. To reduce the influence of the profitability barriers, PMCs must implement innovative strategies to remain at a competitive advantage. Mitigating the impact of the power of suppliers can be made through diversification of source countries to get materials from. PMCs should also introduce innovative and sustainable business and work practices in order to achieve sustainable profitability. It is recommended to future researchers to investigate other components of success factors in order to improve project performance and increase project success.

\section{References}

Antón, A. J. M., Rodríguez, G. S., \& López, Á. R. (2011). Financial risks in construction projects. African journal of business management, 5(31), 12325.

https://doi.org/10.5897/AJBM11.1463

Aston, Ben (2013). 10 top tips for creating timing plans: Establish your planning horizon. Digital Project Manager (DPM). Retrieved from: goo.gl/PyXKeo

Atkinson, Simon (2017 June 5). Qatar row: Economic impact threatens food, flights and football. BBC. Available in: http://www.bbc.com/news/business-40156029

Attwood, Ed (2016 March 16). First phase of Qatar's long-delayed \$7.9bn Sidra megaproject to open in May. Arabian Business. Retrieved from goo.gl/moygcx

Bakar, A. H. A., Razak, A. A., Yusof, M. N., \& Karim, N. A. (2011). Factors determining growth of companies: A study on construction companies in Malaysia. African journal of business management, 5(22), 8753. https://doi.org/10.5897/AJBM10.1142

Belassi, W., \& Tukel, O. I. (1996). A new framework for determining critical success/failure factors in projects. International journal of project management, 14(3), 141-151.

https://doi.org/10.1016/0263-7863(95)00064-X

Brueggen, Oliver (2015). What is the Secret to Successful Project Control and Profitability? ERP Financial Management Business Intelligence Project Management. Retrieved from: goo.gl/CAoVd5

Business Victoria (n.d.). Measuring for success: Focus on key areas to reach your goals. Retrieved from: goo.gl/YJJahp

Cullen, Hope (n.d.). Effective Project Management For Clinical Trials. A Business Approach. Retrieved from: goo.gl/WMe7qo

Dávalos, Isabel Ovalle (2017 April 4). Over QAR 1.4 billion in opportunities for 2022 go on offer to Qatari companies. Supreme Committee for Delivery Legacy. Retrieved from https://www.sc.qa/en/news/over-qar-1-billion-in-2022-fifa-world-cup-opportunities-on-offer-f or-qatari-companies 


\section{Macrothink}

Business and Economic Research ISSN 2162-4860 2018, Vol. 8, No. 2

De Almeida, Pedro Rodrigues and Solas, Manuel Zafra (2016). Shaping the Future of Construction, A Breakthrough in Mindset and Technology. World Economic Forum. REF 220416.

Elkadi, H. (2013). Success and failure factors for e-government projects: A case from Egypt. Egyptian Informatics Journal, 14(2), 165-173. https://doi.org/10.1016/j.eij.2013.06.002

Finch, R. (2011). Tendering Construction Projects. Retrieved from: goo.gl/bYzDw9

Gilmore, Fergus (2017). The challenges of delivering profitable projects in the consulting industry. Consultancy.uk. Retrieved from: goo.gl/f6U8Ug

Gliem, J. A., \& Gliem, R. R. (2003). Calculating, interpreting, and reporting Cronbach's alpha reliability coefficient for Likert-type scales. Midwest Research-to-Practice Conference in Adult, Continuing, and Community Education.

Green, Beata (2015). Measuring the Profitability of your Projects. The Project Manager. Retrieved from: goo.gl/c3BF8y

George, D., \& Mallery, P. (2003). SPSS for Windows step by step: A simple guide and reference. 11.0 update (4th ed.). Boston: Allyn \& Bacon

Hafez, F., \& Aziz, R. (2013). Applying Lean Thinking in Construction and Performance Improvement. Alexandria Engineering Journal. https://doi.org/10.1016/j.aej.2013.04.008

Harned, Brett (2015). A Guide to Project Management. Teamgannt. Retrieved from https://www.teamgantt.com/guide-to-project-management/what-is-project-management

Hyvari, I. (2006). Success of projects in different organizational conditions. Project management Journal, 37(4), 31.

Kanakulya, E. K., \& Jinzhao, W. A. N. G. (2017). The Status of Africa's Construction Industry and its Porter's Five Forces Analysis. International Business and Management, 14(2), 50-53.

Kerr, Simeon (2017 March 1). Qatar's slowing economy puts World Cup spending in spotlight. Doha News. Retrieved from: goo.gl/uS4G4o

Kovessy, Peter (2015 June 18). Sidra's Qatar staff told to expect more delays before hospital opens. Retrieved from: goo.gl/xqXpCd

Kwon, O-Kyung \& Kim, Jong-Hoon (2004). The Roles of Construction Management in Super High-Rise Building Projects. CTBUH 2004 Seoul Conference. Seoul, South Korea.

Labaree, R. V. (2009). Research Guides: Organizing Your Social Sciences Research Paper: Qualitative Methods. Retrieved from http://libguides.usc.edu/writingguide/quantitative

Levinson, Jay Conrad (2007). Easy and Inexpensive Strategies for Making Big Profits from Your Small Business. Guerrilla Marketing, 4th edition. Houghton Mifflin Harcourt. ISBN 9780547347660 


\section{Macrothink

Martin, Marci (2014). Bargaining Power of Suppliers Porter's Five Forces Model. Retrieved from https://www.cleverism.com/bargaining-power-of-suppliers-porters-five-forces/

Martin, Marci (2017). Porter's Five Forces: Analyzing the Competition. Business News Daily. Retrieved from http://www.businessnewsdaily.com/5446-porters-five-forces.html

ME Steel (2017). Construction sector likely to get a jolt amid severance of diplomatic ties with Arab states. Retrieved from: goo.gl/zU47fR

Millhollan, C. (2008). Scope change control: control your projects or your projects will control you! Paper presented at PMI® Global Congress 2008-North America, Denver, CO. Newtown Square, PA: Project Management Institute.

Mochal, Tom (2005). Use this issues management process for resolving major problems. Techrepublic. Retrieved from: goo.gl/7YbfyZ

Mochal, Tom (2016 April 4). 10 best practices for successful project management. Retrieved from: http://coworkspringfield.com/10-best-practices-successful-project-management/

Mohamad, H. H., Ibrahim, A. H., \& Massoud, H. H. (2013). Assessment of the expected construction company's net profit using neural network and multiple regression models. Ain Shams Engineering Journal, 4(3), 375-385. https://doi.org/10.1016/j.asej.2012.11.008

Muhammed, Abdullahi (2016 December 19). 5 Tips for Preventing Scope Creep Without Losing Your Clients. Forbes. Retrieved from: goo.g1/4niGAx

Nenni, M. E., Giustiniano, L., \& Pirolo, L. (2013). Demand forecasting in the fashion industry: a review. International Journal of Engineering Business Management, 5, 37. https://doi.org/10.5772/56840

Öney-Yazýcý, E., \& Acar, E. (2006). Competitive micro environment of small residential building contractors. In 1st International CIB Endorsed METU Postgraduate Conference.

Onsite Ventures (2014 July 23). Qatar's Sidra hospital project facing repeated delays, main contractors sacked. Retrieved from: goo.gl/grihGa

Pamulu, S. (2010). Strategic Management Practices in the Construction Industry: A Study of Indonesian Enterprise. Retrieved from https://eprints.qut.edu.au/41570/

Patel, P. (2009, October). Introduction to quantitative methods. In Empirical Law Seminar.

Pinto, J. K., \& Slevin, D. P. (1988, June). Critical success factors across the project life cycle. Project Management Institute.

Porter, Michael E. (2004). Competitive Advantage, Creating and Sustaining Superior Performance. First Free Press Export Edition. New York

Project Qatar (2017). Qatar Economic Insights. Retrieved from: goo.g1/U8aFma

Qatar Online Directory (2017). Companies in Doha Qatar. Retrieved from: goo.g1/FXu61F

Scott, Victoria (2014 May 12). As recruitment ramps up, still no opening date for delayed 
Sidra. Doha News. Retrieved from: goo.gl/EHVFWZ

Selim, T. H., \& Salem, A. S. (2014). Global Cement Industry: Competitive and Institutional Frameworks. In Econometric Methods and Their Applications in Finance, Macro and Related Fields (pp. 511-531). https://doi.org/10.1142/9789814513470_0018

Serrador, P. (2013). The Impact of Planning on Project Success-A Literature Review. The Journal of Modern Project Management, 1(2). Retrieved from http://www.journalmodernpm.com/index.php/jmpm/article/view/30

Silvius, Gilbert, Schipper, Ron, Julia, van den Brink, Jasper (2017). Sustainability in Project Management. Routledge. ISBN 9781351896566

Söderlund, J. (2004). Building theories of project management: past research, questions for the future. International journal of project management, 22(3), 183-191.

https://doi.org/10.1016/S0263-7863(03)00070-X

Sousa, V. D., Driessnack, M., \& Mendes, I. A. C. (2007). An overview of research designs relevant to nursing: Part 1: quantitative research designs. Revista latino-americana de enfermagem, 15(3), 502-507. https://doi.org/10.1590/S0104-11692007000300022

Taherdoost, H., \& Keshavarzsaleh, A. (2016). Critical Factors that Lead to Projects' Success/Failure in Global Marketplace. Procedia Technology, 22, 1066-1075.

https://doi.org/10.1016/j.protcy.2016.01.151

The Guardian (2017 February 8). Qatar spending \$500m a week on World Cup projects. Retrieved from: goo.gl/wMKbKJ

The Peninsula (2017 September 5). Blockade failed to impact construction sector: SAK. Retrieved from: goo.gl/nKkihy

Trizano-Hermosilla, I., \& Alvarado, J. M. (2016). Best Alternatives to Cronbach's Alpha Reliability in Realistic Conditions: Congeneric and Asymmetrical Measurements. Frontiers in psychology, 7. https://doi.org/10.3389/fpsyg.2016.00769

Walker, Lesley (2016 June 28). Work on multibillion-riyal Doha sewer project suddenly halted. Doha News. Retrieved from: goo.g1/5dNSwt

WBDG Project Planning Committee, (2017). Project Planning, Delivery \& Controls. National Institute of Building Sciences. Retrieved from:

https://www.wbdg.org/project-management

Wilkinson, James (2013). Buyer Bargaining Power (one of Porter's Five Forces) The Strategic CFO. Retrieved from: goo.g1/3Pcx65

Williams, C. (2011). Research methods. Journal of Business \& Economics Research (JBER), 5(3). https://doi.org/10.19030/jber.v5i3.2532

Withers, Iain (2017 June 12). Gulf crisis threatens Qatar's £160bn World Cup building plans. The Telegraph. Retrieved from: goo.gl/u5EJki 


\section{Macrothink}

Business and Economic Research

ISSN 2162-4860 2018, Vol. 8, No. 2

World Construction Network (2017 September 13). Qatar - Gulf crisis and its impact on construction. Retrieved from: goo.gl/WfGUsj

Zakari Tsiga, Michael Emes, \& Alan Smith (2016). Critical Success Factors for The Construction Industry. PM World Journal, V(VII).

\section{Copyright Disclaimer}

Copyright for this article is retained by the author(s), with first publication rights granted to the journal.

This is an open-access article distributed under the terms and conditions of the Creative Commons Attribution license (http://creativecommons.org/licenses/by/3.0/). 